\title{
The Effect of Computer-Assisted Educational Games on Teaching Grammar
}

\author{
Adil Kayan ${ }^{1, *} \&$ İbrahim Seçkin Aydın ${ }^{2}$ \\ ${ }^{1}$ Darıca 60th Year Secondary School, Ministry of National Education, Kocaeli, Turkey \\ ${ }^{2}$ Faculty of Education, Dokuz Eylül University, Izmir, Turkey \\ *Correspondence: Darıca 60th Year Secondary School, Ministry of National Education, Kocaeli, Turkey. E-mail: \\ adil_kayan48@hotmail.com
}

Received: November 17, 2019

Accepted: February 12, $2020 \quad$ Online Published: February 19, 2020

doi:10.5430/wje.v10n1p117

URL: https://doi.org/10.5430/wje.v10n1p117

\begin{abstract}
Discussions on how grammar should be taught have continued for decades. Previous studies have reported that today's students called as Generation Z have shown negative attitudes toward grammar teaching with traditional methods and techniques, and that their academic achievements have failed to meet expectations. Not using methods and techniques that are consistent with the adopted philosophy of education hinders the success of this process. The study investigated the impact of computer-assisted instruction and correspondingly computer-assisted educational games on grammar academic achievement and attitudes toward grammar and Turkish course of students. In this study, a quasi-experimental design based on a quantitative study with a pretest-posttest nonequivalent group was applied. Participants of the study consisted of two classes of $6^{\text {th }}$ grade students studying at a middle school. Computer-assisted educational games were designed and practiced in the experimental group within a 12 -week period. For the control group, activities in the curriculum were followed during lessons. Results showed that grammar academic achievement of students between the experimental group in which computer-assisted educational games were practiced and the control group in which the existing curriculum was followed showed a significant difference in attitudes toward Turkish course and grammar on the behalf of the experimental group. Findings demonstrated that this kind of practice in teaching grammar made a significant difference on achievement and attitude of students. In addition, there was a positive, moderate and statistically significant relationship between attitudes toward grammar and Turkish course. Attitudes toward grammar of students determine attitudes toward Turkish course of students.
\end{abstract}

Keywords: teaching grammar, educational games, computer-assisted educational games, computer-assisted instruction, language teaching

\section{Introduction}

Learning to learn has been viewed as one of the primary goals of education in the 21th century. It has been considered that this goal could be achieved through activities and practices performed in the classroom (Ural, 2009, $\mathrm{p}$. 1). For this reason, according to earlier studies (Altunbay \& Biçak, 2018), traditional approaches and methods have been insufficient to interpret meanings of concepts and bring about learning for students. Prensky (2001) points out that one of the significant reasons of this problem in learning environments is a conflict in language and understanding between educators called as "digital immigrant" and learners named as "digital native". That's to say, trying to make digital natives, who are able to reach the technology in every step of their lives, achieve the goals through teaching methods and techniques used for the previous generation has failed to provide powerful results.

For new generation students who are on the computer for hours and lose track of the time, even short courses in used traditional methods could be boring (Ural, 2009, p. 46). It is owing to the fact that students called as "Generation Z" are exposed to technological tools and materials since their childhood. Therefore, they use technological tools and materials rather than traditional methods to know and learn an object (Prensky, 2001). Academic achievement and motivation of students being exposed to traditional teaching methods in their classroom are decreasing (Sarı \& Altun, 2016, p. 554). Nonetheless, motivation and therefore improving attitude are among indispensable factors for effective 
learning. Teachers have had problems in developing these factors in the classrooms that are getting crowded (Ural, 2009, p. 2).

In today's crowded classrooms, it is required to learn much more knowledge in a short time. In order that time in class is managed effectively and efficiently, it is a key concern to possess new methods and techniques. Among technological tools and materials, computers have been identified as one of the most effective tools which serve those purposes in a classroom environment (Alkan, 2005, p. 4-5). For that purpose, an attempt to find an alternative method to practices that make students passive and an observer in the classroom has been made and it has been started to tend to computer-assisted instruction within the scope of technological developments (Demirci, 2008, p. 4-5). Together with computer-assisted instruction, computer games have also become one of the primary materials used to improve the quality of education. Computer games are essential in interpreting knowledge and making learning long lasting (Alessi \& Trollip, 2001). It has been recognized as crucial that the computer games consist of entertaining and motivating factors (Squire, 2003). It is a widely held view that using educational computer games in the classroom could solve several problems concerning learning (Ural, 2009). With reference to those ideas, educational computer games have commonly been assumed to use for problems in teaching grammar.

Teaching grammar plays a vital role in creating language awareness of students (Sever, 2015, p. 29). It has been reported that even if grammar has been taught from the primary school to the college, students have difficulty in using the language and therefore they do not use the language effectively and efficiently (Aly1lmaz, 2010, p. 729). Previous studies regarding this field (Alyılmaz, 2010; Daloğlu, 2005; Demir \& Yapıc1, 2007; Demirkol, 2007; Durukan, 2010; Erdem, 2007; Erdem \& Başaran, 2010; Gülsevin \& Boz, 2006; Sağır, 2002; Şahinci, 2011; Yalçın, 2002; Yaman, 2011; Yapıc1, 2004) have identified that the desired success in schools with regard to teaching grammar has not been achieved yet.

Some underlying reasons for the failure of teaching grammar in schools are listed:

- Viewing teaching grammar as making students memorize certain rules of grammar

- Word-oriented rules of grammar

- Insufficient tools and materials used

- Conflict of term and definition

- Not having an understanding of functional grammar

- Teachers who could not follow recent developments

- Non-functional practices

- Not transforming knowledge into skills

- Not drawing on current approaches of linguistics

- Not raising awareness of students on teaching grammar

- Insisting on using traditional methods and techniques

- Not adopting an approach developing perceptual and productive skills

- Teaching grammar as an independent course

- Not viewing grammar as a whole in terms of form and meaning

- Using knowledge-oriented testing and evaluation methods

- Curriculum issues

- Insufficient course books and etc. (Akkaya, 2011, p. 10; Çiftçi, 2006, p. 120-121; Demir, 2009, p. 60-65; Güneş, 2013, p. 174; İşcan \& Kolukısa, 2005, p. 300-305; Karadüz, 2007, p. 282; Kerimoğlu, 2016, p. 196; Sağır, 2002, p. 31; Sever, 2015, p. 31; Şimşek, 1997, p. 60; Yaman, 2006, p. 21; Ünalan, 2001, p. 141).

Briefly, on the grounds that new methods and techniques in teaching grammar have not been used in the classroom and that the content of grammar has been taught abstractly and explicitly, the success in teaching grammar has not been achieved and students have showed negative attitudes toward the lesson of grammar (Güven, 2013). If the success in teaching grammar is expected to be gained, it is a must to change those methods and techniques together with those approaches used (Demir, 2003, p. 407). Hence, it has commonly been assumed that supporting learning environments with technology-based practices will provide certain improvements in students' achievement and attitudes (Altunbay \& Bıçak, 2018, p. 140). 
Girls sit on the computer for 5.5 hours per week while boys spend their time on the computer for 13 hours per week. The elapsed time has been increasing day-by-day (Yağız, 2007). Considering the amount of time of playing games, Turkey has ranked 3rd worldwide while it is far from this rank concerning using games in learning and teaching (Y1lmaz, 2018, p. 18). Using educational computer games in education has been claimed to be a necessity because children are very interested in computers and computer games, and because computers and their applications have become great parts of our lives. Along with those practices setting enjoyable learning environments, transforming knowledge into skills and therefore making it long lasting seem possible (Bayırtepe \& Tüzün, 2007). One of the key fields in which skill-based instruction should be adopted is language teaching.

Today, several developed countries have placed an emphasis on language and language teaching. Teaching methods and techniques which will be developed together with models and approaches which will be used during that process have been thought as vital (Güneş, 2016, p. 13). Nevertheless, as grammar has still been taught with a mentality based on rote learning in schools (Demir, 2003, p. 407), the contribution of grammar to language teaching is regarded as unsatisfactory (Kerimoğlu, 2016). According to Güneş (2013, p. 172), from past to present, rules and definitions have been memorized and in-depth grammatical analysis has been practiced during grammar lessons. Instead of reasoning and skill, a rule-based understanding has been adopted. Because of those reasons, it has been detected that it affects students' psychology negatively, for example, some students are bored or some of them feel frightened during grammar lessons. Especially for primary school students who are just passing the concrete operational stage through the formal operational stage, it is significant that rules and definitions are concreted and given implicitly (Durukan, 2011, p. 42). At this point, it has been regarded as a major problem that different methods and techniques have not been used in teaching grammar. That problem has a negative impact on academic achievement and attitudes of students who do not quiet comprehend course contents (Güven, 2013).

The present study aimed so as to examine the impact of computer-assisted instruction and correspondingly computer-assisted educational games on grammar academic achievement on Turkish course of students and attitudes toward grammar and Turkish course of students. The using of technology-based platforms with traditional approaches by teachers impedes to take advantage of earlier practices properly. It has been thought that this computer-assisted study supported by constructivist software and educational games directly affects academic achievement on grammar and attitudes of students. A considerable amount of literature has been published on academic achievement, attitude, self-efficacy, opinions of students and teachers related to computer-assisted instruction and computer-assisted educational games. The related publications and studies have reported that these methods have often provided positive changes on academic achievement and attitude. No studies have been found in the literature related to an experimental research on the using of "computer-assisted educational games" in teaching grammar of Turkish. For this reason, it has been proposed that the current study will serve as a base for future studies and draw attention to the gap in the field.

\subsection{Research Questions}

Considering the research gap in the field, the study addressed the following research questions:

1. Is there a statistically significant difference in the results of the pretests of grammar achievement, attitudes toward grammar and attitudes toward Turkish course of students between the experimental group and the control group?

2. Is there a statistically significant difference in the results of the posttests of grammar achievement, attitudes toward grammar and attitudes toward Turkish course of students between the experimental group and the control group?

3. Is there a statistically significant difference in the results of the pretests and the posttests of attitudes toward grammar and attitudes toward Turkish course of students between the experimental group and the control group?

\subsection{Literature Review}

According to Durukan (2012, p. 145), students show positive attitudes toward instruction software. The experimental group in the study of Durukan (2012) demonstrated improvements in academic achievement together with positive attitudes. The research has put forward that using such software in grammar teaching results in a significant difference in academic achievement and attitudes of students. Besides, the findings of Ural's study (2009, p. 46) have shown that using educational computer games prevents students from being bored, worry, and anxious during lessons and provides an enjoyable, peaceful, and motivating learning environment as well. Students participate enthusiastically in the lessons where educational computer games are practiced. The findings have also reported that students in the experimental group desire to practice educational computer games in every lesson.

Kulik (1983) has carried out a meta-analysis comparing with the results of fifty-one studies each other. The findings have indicated that computer-assisted instruction is more effective than traditional education on academic 
achievement and attitudes. Randel et al. (1992) have investigated sixty-seven studies concerning educational games on academic achievement, attitude, and persistency of learning. Of the 67 studies, 27 of those have resulted in favor of educational games while 38 of them have concluded that there is no significant difference between traditional education and educational games.

In a study that set out to determine the effects of computer-assisted instruction and traditional education on academic achievement by Kamacı and Durukan (2012), 10\%-18\% positive results on the behalf of computer-assisted instruction have been obtained. Similarly, investigations on over 200 studies by Bangert-Drowns (1985) have asserted that computer-assisted instruction increases the rate of academic achievement up to $20 \%$. In another meta-analysis regarding 43 experimental studies on the impact of computer-assisted instruction on academic achievement conducted between the years of 2007 and 2017, the results obtained have demonstrated that there is a strong relationship between computer-assisted instruction and academic achievement (Dikmen \& Tuncer, 2018).

In Durukan's (2011) research attempting to examine the effect of computer-assisted instruction on academic achievement in Turkish courses, attitudes towards Turkish courses, and persistency of learning, Durukan (2011) has reported that computer-assisted instruction has increased academic achievement of students much more than traditional education. While Buran (2008) proposes that computer-assisted instruction is more effective than currently available curriculum practices in terms of the development of listening skill, Zobar (2011) highlights that computer-assisted instruction is more profound than traditional methods with regard to achievement on reading and writing. While earlier studies on Turkish and grammar teaching have been related to computer-assisted instruction, the current study identifies the impact of computer-assisted educational games on teaching grammar.

\subsection{Computer-assisted Instruction}

Computer-assisted instruction is a teaching method in which computers are used in learning environments; in which motivation of students is increased and opportunities of individual learning at one's own pace are available; in which the process of learning is strengthened (Güllüoğlu, 2010, p. 2; Koşar, 2004, p. 124; Uşun, 2004, p. 42). It is a term used to explain an instruction in which computers are regarded as a supplementary and powerful component of the system rather than an option, and an instruction through which tools help making course subjects be presented with certain software in the process of learning. Within that process, other methods and techniques are also practiced together (Akkoyunlu, 1993, p. 41; Durukan, 2011, p. 76; Uşun, 2004, p. 40). One of them is games.

\subsection{Games}

A game is defined by the Turkish Language Association as "an entertainment which is skill- and brain-training, has certain rules, makes somebody have a great time" (TDK, 2019). Games are enjoyable activities which exercise influence over both participants and audience through some factors such as skill, luck, intelligent, attention used by groups constituted on a voluntary basis in the frame of certain time, place and rules out of vital activities (Hazar, 1996, p. 7). Games are divided into subheads such as educational games, computer games, and educational computer games.

\subsubsection{Computer Games}

Computer games are entertainment environments where people have lots of fun without feeling obligated to do it, and where there are restricted certain rules in their own right out of the outer world (Garris, Ahlers, and Driskell, 2002, p. 43). They provide people with developing critical skills by establishing a connection with real life (Turvey, 2006). Along with those, they support individual learning by contributing the development of several skills (McFarlane, Sparrowhawk, and Heald, 2002, p. 13). Skills such as problem solving, creativity, and critical thinking are among some examples of promoting personal development skills (Berson \& Berson, 2003). In addition, it has been viewed that computer games have a significant role in perception and interpretation of activities, and making decision in critical situations (Odabaş1, 2008, p. 141). Computer games are excellent learning tools. They provide learners with an opportunity of adjusting the level of difficulty of games and playing them again and again (Hostetter, 2002). A number of previous experimental studies have been reported that games have offered successful results even in teaching complex subjects. Interests and desires of gamers could ensure them to be motivated in learning these subjects and to achieve their educational goals (Garris, Ahlers, and Driskell, 2002, p. 441-442).

\subsubsection{Educational Games}

Educational games are games developed with the precise aim of education (Üçgül, 2006). They are entertaining activities which are designed so as to increase learners' motivation and provide a qualified and persistent learning; which are competitive; which have limited specific rules; and which require certain skills and creativity (Ak1ll, 2007, p. 4). They play a key role in achieving education goals in a shorter time (Köseoğlu, 2012, p. 25). They are also 
called as serious games (Y1lmaz, 2017). Serious games have stories and win-lose situations as well. They involve in entertainment elements and socialization environments. Their environments and characters are so real-like (Y1lmaz, 2017, p. 172; Y1lmaz, 2018, p. 28).

Educational games used in education are amusing activities which are suitable for students' age, level, gender, ethical rules, making students have terminal behaviors. Not only do they promote using the time efficiently, but also they provide learning while having fun (Sönmez, 1993, p. 294). Educational games which improve creativity and imagination also help knowledge to be reinforced through individual and group works (Uğurel, 2003, p. 43). According to Gradler (1994, p. 28), educational games are used to apply to or examine essential knowledge and skills, determine imperfections in knowledge and skills, and serve as a summary or review and make a connection between principles and concepts. Prensky (2007, p. 107) suggests seven features that should be included in educational games below:

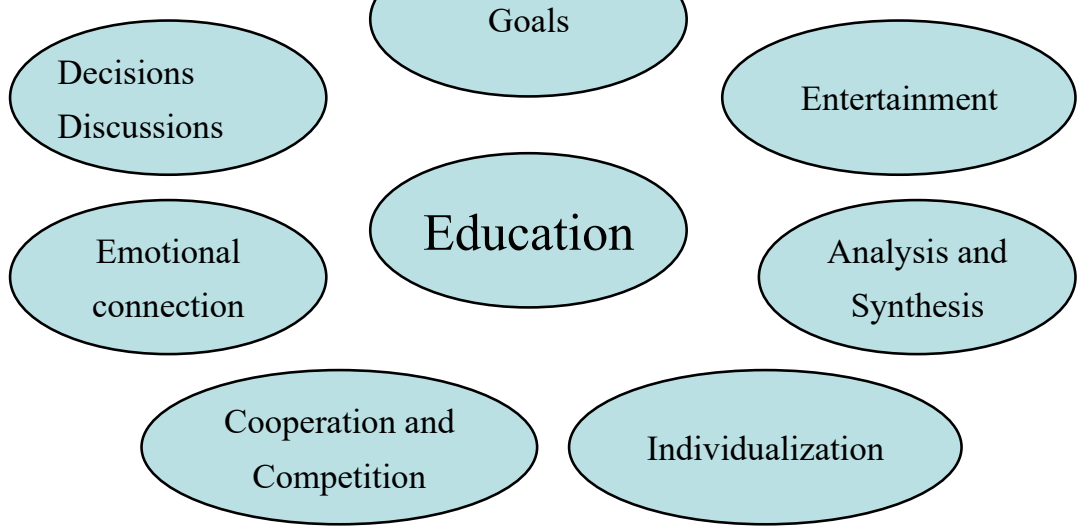

\subsubsection{Computer- assisted Educational Games}

Computer-assisted educational games have been a trend topic in recent years as a result of the adaptation of computer games into education. They are a kind of game created through adjusting entertaining and motivating computer games in order to increase the quality of education (Ural, 2009, p. 18). They are game-assisted software which facilitates learning course contents (Güngörmüş, 2007, p. 18), and developing problem-solving skills (Demirel, Seferoğlu, \& Yağcı, 2003, p. 141). It is one of the most effective methods to achieve course objectives (Akpınar, 1999). Techniques used to draw attention and increase motivation of students can be used as both a supplementary material and a material in itself (Kiili, 2005). It is a learning method based on students' voluntarily participation without any pressure or force (Malta, 2010, p. 37), supporting learning by fun (Taşdemir \& Şüyun, 2016, p. 123).

Educational computer games provide opportunities to develop several skills of students by supplying stress-free, flexible learning environments to them (Boyle, 2011, p. 3-4). The opportunity for repetitions ensures to internalization and consistency of knowledge learned (Y1lmaz, 2017, p. 162). Not only are they for fun, but also they are for the reinforcement of knowledge. Therefore, they could be drawn on achieving course objectives (Bayırtepe \& Tüzün, 2007).

Computer-assisted educational games support multiple intelligences and active learning. While they are helping to make knowledge permanent, they also make learning enjoyable (Uğurel, 2003, p. 42). Educational computer games are applications which have the fastest learning curve. While playing, students are learning as well (Siang \& Rao, 2003). The knowledge learned is gripped very fast. They are placed into long-term memory (Taşdemir \& Şüyun, 2016, p. 123). They are effective in developing students' skills of psychomotor, visual and reasoning and in increasing their speed of reaction to stimuli (Sardone \& Devlin-Scherer, 2009, p. 50).

They are effective in increasing motivation of students, and attracting their attentions and their willingness to learn. Along with learning by doing and experiencing, active participation to learning process is enabled (Şahin, 2016, p. 30). According to Kirriemur and McFarlane (2004), they are practiced to increase motivation by having fun and enhance to learning by doing and experiencing. Linderoth, Lantz-Andersson and Lindström (2002) point out that educational computer games are exercised to teach course subjects, as a motivation source for students, and to improvise real life through simulations. 


\subsection{Design Phase}

While games are one of the most effective learning methods during the ages of preschool, it would not be right to say that learning cannot be associated with entertainment in education environments (Ural, 2009, p. 2). However, the fact that a practice is fun does not mean that it is beneficial to development and learning (Yllmaz, 2017, p. 144). For this reason, while designing a practice, its objectives are determined considering which skills among cognitive, affective and psychomotor skills are developed (Seferoğlu, 2006). Important parts and summaries on subjects are presented without too much knowledge. Visuals are proportioned equally (Yanpar \& Yıldırım, 1999, p. 27-31). Radoff (2011) indicates that during designing games, in addition to those, some entertainment factors should be included: visual, historical, affective, mathematical themes and environments a gamer are interested in. A well-balanced proportion of educational contents and these entertainment factors are very crucial (Smith \& Mann, 2002).

Knowledge, talent and skill instead of chance should be determinant for success in games. It should include no qualities such as a situation in which one of them is winner; the others are losers (Gredler, 2004). Dempsey et al. (Dempsey et al., 2002, p.157-168) address that when gamers have a right to control games; when games have a good quality of screen design; when colors, audios, and animations in games are appropriate and have a well-balanced proportion, the games draw students' attention. In accordance with these principles, course contents and games are designed at the same time in the frame of expert opinions by taking into consideration course objectives (Bates, 2004, p. 80).

In the study, the effect of computer-assisted educational games on teaching grammar has been investigated. To design the software, a program called as "Scratch" has been utilized. Scratch is a programing language which is suitable for every age group, fun, and attracts users' attention to itself with a user-friendly interface. It was designed for people in the 8-16 age group by the MIT (Massachusetts Institute of Technology) in 2003. In time, it has become a programing language which people in every age group could be used. Thanks to its easy and clear interface, it is software created based on dragging code blocks without a need of knowledge of coding (Scratch About, 2015).

Scratch which promotes problem-solving and provides several positive feedbacks is an ideal programing language to be used for educational purposes (Genç \& Karakaş, 2012, p. 982-986). It could be applied in several courses by being drawn on animation, visual, music and effects of Scratch (Çatlak, Tekdal, \& Baz, 2015). Games designed through this program starts with a demo. Following the demo, the goals and rules of the game are clearly explained. Then, the story and scenario of the game are reflected on the screen. Feedbacks about decisions of the gamer are given to him/her (Korkusuz \& Karamete, 2013, p. 89). Earlier studies shows that Scratch has had a positive effect on achievement and motivation of students (Sanjanaashree, Kumar, \& Soman, 2014; Ching-San \& Ming-Horng, 2012).

\section{Method}

\subsection{Research Design}

In the study, a quasi-experimental design based on a quantitative study with a pretest-posttest nonequivalent group was applied. According to Büyüköztürk (2016, p. 205), "When a design provides an opportunity of finding out the beginning point of groups related to the measured quality, and therefore measuring and testing any change, this increases its usefulness. The focus of that kind of design is often to test to the extent to which the change observed in one group is different from the change observed in another group."

\subsection{Participants}

Participants of the study consist of two groups with six-grade students at the same level studying at a middle school in Kocaeli, Turkey. Each group includes 35 participants. The fact that the school has a good quality of technological infrastructure and that students at the school have a tablet have been a key factor to determine the participants.

Table 1. Characteristics of the Participants

\begin{tabular}{llllll}
\hline & & \multicolumn{2}{c}{ Control Group (35) } & \multicolumn{2}{c}{ Experimental Group (35) } \\
\cline { 3 - 6 } & & $F$ & $\%$ & $f$ & $\%$ \\
\hline \multirow{2}{*}{ Gender } & Female & 16 & 45.71 & 20 & 57.14 \\
& Male & 19 & 54.26 & 15 & 42.86 \\
\hline
\end{tabular}




\subsection{Data Collection Instruments}

The Turkish Course Attitude Scale, which is reliable and valid, developed by Ünal and Köse (2014) as a scale of attitude toward Turkish course, and the Grammar Attitude Scale developed by Pehlivan, Aydın and Uyumaz (2018) as a scale of attitude toward grammar were conducted. As a grammar academic achievement test, Durukan's (2011) Grammar Achievement Test was applied.

The reliability analysis demonstrated that the value for Cronbach Alpha of the Grammar Achievement Test was found as 0.837 . The average difficulty index (p) of the Grammar Achievement Test was measured as 0.56 while the average discrimination index ( $r$ ) was measured as 0.42. The value for Cronbach Alpha of the Turkish Course Attitude Scale was found as 0.914. In addition, the Grammar Attitude Scale's Cronbach Alpha value was calculated as 0.887.

\subsection{Data Collection Process}

The study was conducted in two phases. While, in the first phase, computer-assisted educational games and practices to use in a computer-assisted learning environment were developed, in the second phase, whether or not these developed materials in the first phase were effective were investigated. To decide the software for the course to use in the practice part of the study, writing systems were investigated and the program of Scratch was found to be suitable for the study. It was determined that parts of speech which was consistent with the objectives in the $6^{\text {th }}$ grade Turkish Teaching Program based on the Ministry of National Education were supposed to be taught through the program of Scratch in company with the computer-assisted games and practices. The reason why this subject was chosen has been that the practice time of the study coincided the time when the subject selected was supposed to be taught in the curriculum.

- Pre-Practice: The computer-assisted educational games were designed in the frame of previous studies and expert opinions. Feedbacks from informatics teachers, Turkish teachers, and academicians about the current practices were also gotten. With reference to the feedbacks, the games and the practices were revised. They were implemented to $7^{\text {th }}$ grade students studying at the same school during Turkish courses. Feedbacks from the students were gotten in both a written form and a spoken form. Accordingly, some slight changes were made. A plan for 12 weeks to teach grammar based on the curriculum was organized. In the plan, which subjects would be taught, how and how long they would be taught, which methods, techniques and applications would be used were listed. The Grammar Achievement Test, the Turkish Course Attitude Scale, and the Grammar Attitude Scale were applied as a pretest, data were collected from the students, and then the appropriateness of the method was confirmed by comparing the data from the experimental group with the data from the control group.

- During-Practice: Within the frame of the plans, each lesson started with presenting videos, animations or various visuals and therefore students' attentions were attracted to the lesson, then some questions about the contents of the practices were asked to the students. These questions included some statements which aimed to make the students be aware of and discover the rules of grammar. Texts in the course book were presented on a smart board and words related to the subject were underlined. Thus, the students had an opinion about the use of those words. Through presentations of some examples and different uses of those words on digital education platforms, the students had an opportunity to find out their definitions on their own. The students who discovered the rules of grammar through implicit learning practiced the subject by using available educational applications on the smart board. Games were played on the smart board and the students' tablets. The students were divided into groups of 5 or 6 . Each group had a symbolic name and a symbolic visual. Groups were changed according to the order of the list per week. Hence, students with different levels could be worked in the same group. The students prioritized the group success within cooperation rather than the success of an individual and as a result, they developed their skills such as sharing and helping with each other. They listened to different ideas, criticized them, and stated whether they agree or disagree with. This also enabled peer teaching among the students. During playing the games, these group works were often administered. The students discussed and made a decision with their group members, then the decisions were written on a cardboard and explained to the rest of the class. As to tablets, the educational games were played individually via them. After the games played as a group work, feedbacks were given to each student, and therefore all of them were able to feel as a winner rather than feel as if while one of them was the winner, the rest of them were the losers. The necessary applications were set up in the tablet of each student and ensured that they made repetitions at home. The computer-assisted educational games were applied both in the phase of practice and in the evaluation of what was learned. It took two course hours a week during 12 weeks.

- Post-Practice: Posttests were conducted to determine whether the students show a difference in their academic achievement, attitudes toward Turkish course and grammar at the end of the 12-week period. 


\section{Results}

\subsection{Statistics and Data Analysis}

Before data analysis, the negatively worded items in the Turkish Course Attitude Scale and the Grammar Attitude Scale were reverse-coded. Then, missing values and outliers were examined and after all, none of them was found in the analysis. To measure the reliability of the items' scores in the scales, the Cronbach Alpha internal consistency coefficients were estimated. The estimated Cronbach Alpha coefficients were calculated as 0.923 in the pretest of the Turkish Course Attitude Scale course and measured as 0.929 in the posttest of the Turkish Course Attitude Scale while it was found as 0.887 in the pretest of the Grammar Attitude Scale and calculated as 0.887 in the posttest of the Grammar Attitude Scale. It has showed that the scores obtained from the scales are highly reliable (Özdamar, 2004). The normality of the data was tested and has been presented in Table 2 .

Table 2. Test of Normality

\begin{tabular}{lllll}
\hline & & Shapiro-Wilk & & p \\
& Group & SW & Sd & .422 \\
Grammar Achievement Pretest & Experimental & .969 & 35 & .686 \\
Grammar Achievement Posttest & Control & .978 & 35 & .039 \\
Grammar Attitude Pretest & Control & .974 & 35 & .574 \\
Grammar Attitude Posttest & Experimental & .952 & 35 & .133 \\
Turkish Course Attitude Pretest & Control & .981 & 35 & .795 \\
Turkish Course Attitude Posttest & Experimental & .987 & 35 & .943 \\
& Control & .968 & 35 & .384 \\
& Experimental & .907 & 35 & .006 \\
& Control & .948 & 35 & .101 \\
\hline
\end{tabular}

It is apparent from Table 2 that the scores of the grammar achievement posttest and the Turkish course attitude pretest and posttest were normally not distributed. Besides, the lower limit of using non-parametric tests for the number of observation/participant in groups is 30 (Delice, 2010 as cited in Ross, 2004; Sümbüloğlu \& Sümbüloğlu, 1993). The number of the participants in the subgroups is very close to the lower limit. Due to the fact that normality distribution in small sample sizes is generally incidental, the Mann Whitney U test and the Wilcoxon signed-rank test were conducted to find out an answer to the sub-problems. In order to determine the correlation between two continuous variables, the Spearman Brown formula was calculated.

Findings about the sub-problems are explained below.

Is there a statistically significant difference in the results of the pretests of grammar achievement, attitudes toward grammar and attitudes toward Turkish course of the students in the experimental group and the control group? The results of the Mann Whitney $U$ test conducted to answer this question are presented in Table 3.

As shown in Table 3 that before applying the computer-assisted educational games, there is no statistically significant difference in the scores of grammar achievement pretest $(U=579.000, p>0.05)$, grammar attitude pretest $(U=461.500$, $p>0.05$ ), and Turkish course attitude pretest $(U=607.000, p>0.05)$ of the students between the experimental group and the control group. The second sub-problem of the study asks whether there is a statistically significant difference in the scores of the posttests of grammar achievement, attitudes toward grammar and attitudes toward Turkish course of the students between the experimental group and the control group. The results of the Mann Whitney $U$ test applied to find out an answer to this question are summarized in Table 4. 
Table 3. Differences in the Results of the Pretests between the Experimental Group and the Control Group

\begin{tabular}{|c|c|c|c|c|c|c|}
\hline & Group & $\mathrm{N}$ & Mean Rank & Sum of Ranks & $\mathrm{U}$ & $\mathrm{p}$ \\
\hline \multirow[t]{3}{*}{ Grammar Achievement Pretest } & Experimental & 35 & 34.54 & 1209.00 & 579.000 & .691 \\
\hline & Control & 35 & 36.46 & 1276.00 & & \\
\hline & Total & 70 & & & & \\
\hline \multirow[t]{3}{*}{ Grammar Attitude Pretest } & Experimental & 35 & 31.19 & 1091.50 & 461.500 & 076 \\
\hline & Control & 35 & 39.81 & 1393.50 & & \\
\hline & Total & 70 & & & & \\
\hline \multirow[t]{3}{*}{ Turkish Course Attitude Pretest } & Experimental & 35 & 35.66 & 1248.00 & 607.000 & 948 \\
\hline & Control & 35 & 35.34 & 1237.00 & & \\
\hline & Total & 70 & & & & \\
\hline
\end{tabular}

Table 4. Differences in the Results of the Posttests between the Experimental Group and the Control Group

\begin{tabular}{|c|c|c|c|c|c|c|}
\hline & Group & $\mathrm{N}$ & Mean Rank & Sum of Ranks & $\mathrm{U}$ & $\mathrm{p}$ \\
\hline \multirow[t]{3}{*}{ Grammar Achievement Posttest } & Experimental & 35 & 42.64 & 1492.50 & 362.500 & .003 \\
\hline & Control & 35 & 28.36 & 992.50 & & \\
\hline & Total & 70 & & & & \\
\hline \multirow[t]{3}{*}{ Grammar Attitude Posttest } & Experimental & 35 & 45.93 & 1607.50 & 247.500 & 000 \\
\hline & Control & 35 & 25.07 & 877.50 & & \\
\hline & Total & 70 & & & & \\
\hline \multirow[t]{3}{*}{ Turkish Course Attitude Posttest } & Experimental & 35 & 43.44 & 1520.50 & 334.500 & .001 \\
\hline & Control & 35 & 27.56 & 964.50 & & \\
\hline & Total & 70 & & & & \\
\hline
\end{tabular}

Table 4 illustrates that there is a statistically significant difference in the scores of grammar achievement posttest $(\mathrm{U}=362.500, \mathrm{p}<0.05)$, grammar attitude posttest $(\mathrm{U}=247.500, \mathrm{p}<0.05)$ and Turkish course attitude posttest $\mathrm{U}=334.500, \mathrm{p}<0.05$ ) of the students between the experimental group and the control group after the practices of the computer-assisted educational games. It shows that the difference is in the favor of the experimental group. In other words, the posttest scores of grammar achievement, Turkish course attitudes and grammar attitudes of the students in the experimental group are higher than the posttest scores of students in the control group. Along with that there is a significant difference in the scores of the pretest and the posttest of grammar achievement of the students in the control group, the practices of the computer-assisted educational games have resulted in that grammar achievement of the students in the experimental group is statistically and significantly more higher than the control group's grammar achievement.

The third sub-problem of the study has investigated whether there is a significant relationship in the pretest and posttest scores of grammar attitudes and Turkish course attitudes of the students between the experimental group and control group. The Spearman Correlation Coefficients calculated in order to answer this question are illustrated in Table 5 below. 
Table 5. Relationship in the Pretest-posttest of Grammar Attitude and Turkish Course Attitude between the Experimental Group and the Control Group

\begin{tabular}{llll}
\hline Group & & $\mathrm{r}$ & $\mathrm{p}$ \\
\hline Experimental & Grammar Attitude Pretest- Turkish Course Attitude Pretest & 0.615 & 0.000 \\
& Grammar Attitude Posttest- Turkish Course Attitude Posttest & 0.681 & 0.000 \\
\multirow{2}{*}{ Control } & Grammar Attitude Pretest- Turkish Course Attitude Pretest & 0.379 & 0.025 \\
& Grammar Attitude Posttest- Turkish Course Attitude Posttest & 0.689 & 0.000 \\
\hline
\end{tabular}

$\mathrm{N}=3 \overline{5}$

Table 5 shows that there is a positive, moderate and statistically significant relationship between the scores of grammar attitude pretest and Turkish course attitude pretest of the students in the experimental group ( $\mathrm{r}=0.615$, $\mathrm{p}<0.05$ ). Accordingly, it can be deduced that the increase in the scores of grammar attitude pretest of the students will lead to a moderate and statistically significant increase in the scores of Turkish course attitude pretest of the students. Also, it has been found out that there is a positive, moderate and statistically significant relationship between the scores of grammar attitude pretest and Turkish course attitude pretest of the students in the control group ( $\mathrm{r}=0.379$, $\mathrm{p}<0.05$ ). This could be explained that the increase in the scores of the grammar attitude pretest of the students in the control group will result in a low level and statistically significant increase in the scores of Turkish course attitude posttest of the students in the control group.

As can be seen in Table 5, it has been brought to conclusion that there is a positive, moderate and statistically significant relationship between the scores of grammar attitude posttest and Turkish course attitude posttest of the students in the experimental group $(\mathrm{r}=0.681, \mathrm{p}<0.05)$. This could be summarized that the increase in the scores of grammar attitude posttest of the students in the experimental group will cause a moderate and statistically significant increase in the scores of Turkish course attitude posttest. Also, it has been found out that there is a positive, moderate and statistically significant relationship between the scores of grammar attitude posttest and Turkish course attitude posttest of the students in the control group $(\mathrm{r}=0.689, \mathrm{p}<0.05)$. In other words, the increase in the scores of grammar attitude posttest of the students in the control group will cause a moderate level and statistically significant increase in the scores of Turkish course attitude posttest of the students in the control group.

\section{Discussion}

In the favor of the experimental group, a significant difference in grammar academic achievement between the experimental group in which the computer-assisted educational games were practiced and the control group in which current practices in the curriculum were applied has been observed. It has been concluded that computer-assisted educational games are more effective in increasing grammar academic achievement. Also, it has been found that a significant difference has been observed in the scores of the pretest and the posttest of grammar achievement of the students in the control group. It can be reported that adopting the constructivist approach in the control group as well could lead to this significant difference.

Similar results have been obtained from earlier studies related to language teaching. In the study of Durukan (2011) in which the effect of computer-assisted instruction on students' academic achievement of Turkish course has been investigated; in the research of Buran (2008) in which the impact of computer-assisted education on listening skill has been examined, and in the study of Zobar (2011) in which the success of computer-assisted instruction on reading and writing has been analyzed, it has been reported that computer-assisted instruction is more effective than traditional methods. Similar results have been detected in previous studies from different fields:

In the field of teaching mathematics, the impact of (a) educational computer games (Tural, 2005; Öztürk, 2007); (b) computer-assisted instruction (Uygun, 2008; Bayturan, 2011); (c) computer games (Kebritchi, Hirumi, \& Bai, 2010); and (d) computer-assisted applications (Ragasa, 2008) on academic achievement;

In the field of teaching science, the effect of (a) educational games (Şaşmaz, Ören, \& Avc1, 2004); (b) computer-assisted instruction with the constructivist software in biology class (Pektaş, 2008); (c) computer-assisted instruction in biology course (Kara, 2009); (d) computer-assisted instruction in physics course (Ergörün, 2010); (e) computer-assisted instruction in science and technology course (Güven \& Sülün, 2012) on academic achievement;

In the field of teaching English, the effect of (a) educational games (Taşl1, 2003); (b) computer-assisted educational 
games in teaching English grammar (Shagga \& Omar, 2012); (c) computer-assisted instruction in teaching English grammar (Naba'h, Hussain, Al-Omari, \& Shdeifat, 2009); (d) educational computer games in English teaching (Donmuş, 2012) on academic achievement;

In the field of informatics, the impact of (a) web-based educational games (Güngörmüş, 2007); (b) digital games-based learning (Papestrergiou, 2009); (c) ClassDojo learning environment (Özer, 2016) on academic achievement;

In the teaching of social sciences, the impact of educational computer games (Polat \& Varol, 2012) on academic achievement have been investigated and resulted in a significant difference in favor of the experimental group.

There are also other published studies which do not support the findings of the current study. Kula and Erdem (2005) found no significant difference in the effect of educational computer games on achievement of mathematics in their study. Bayırtepe and Tüzün (2007) examined the impact of game-based learning environments on computer course achievement and no significant difference between the experimental group and the control group was obtained. Yiğit (2007) inquired the effect of computer-assisted educational games on achievement of mathematics of students and obtained no significant difference between the groups. Yağız (2007) examined the impact of game-based learning on computer-assisted instruction and no significant difference was detected between the experimental group and the control group.

In the favor of the experimental group, a significant difference between the experimental group in which the computer-assisted educational games were practiced and the control group in which current practices in the curriculum were applied in terms of attitudes toward grammar and Turkish course has been observed. No significant difference in the results of the pretest and posttest of the attitudes of the control group was found. Appearance of some characters fed by traditional culture (e.g. Keloğlan, Nasrettin Hoca, Evliya Çelebi, Hezarfen, Dede Korkut) in games has affected significantly increasing the attitudes of students in the experimental group.

Similar results have been observed in the studies of Durukan (2011) and Zobar (2011). However, there are some studies which have been unable to demonstrate the results of the current study. It was concluded that there was no significant difference (a) in the effect of computer-assisted instruction with an constructivist approach on attitudes toward biology course (Pektaş, 2008); (b) in the impact of the computer-assisted instruction on attitudes toward mathematics course (Uygun, 2008; Bayturan, 2011; Ragasa, 2008); (c) in the effect of the computer-assisted education as a method on attitudes toward biology course (Kara, 2009); (d) in the effect of the computer-assisted instruction on attitudes toward to science course (Güven \& Sülün, 2012) between the experimental group and the control group.

In the studies mentioned above which have demonstrated different results from the current study, the reason why the attitudes did not show a positive change could be based on the duration of the practices and the quality of the software used. Also, the fact that earlier studies have not been conducted long enough to be able to change the attitudes positively, the fact that the software has not included entertaining elements and it has not been appropriate to the ages and levels of students, that the computer-assisted instruction has been used only as a knowledge transmitter can be among the causes of these results.

As a conclusion, according to the results of the pretests and the posttests obtained from the experimental group in which the computer-assisted educational games were practiced and the control group in which current subjects in the curriculum were followed, there is a positive, moderate, statistically significant relationship between the attitudes toward grammar and the attitudes toward Turkish course. The attitudes toward grammar determine the attitudes toward the Turkish course of students.

\section{Conclusion}

As a result of this experimental study, the experimental group in which the computer-assisted educational games were practiced showed an increase in grammar academic achievement in attitudes toward Turkish course and grammar comparing to the control group. Besides, the increase in adopting attitudes toward grammar positively influenced the increase in adopting attitudes Turkish course. It was revealed that the approaches and methods used in grammar teaching had also an influence over shaping attitudes toward the language.

Although the traditional methods practiced in the control group helped to enhance the success, it did not reach the level of success which the computer-assisted educational games reached. Furthermore, it was detected that the computer-assisted educational games had a significant role in improving learning together with attitude. As a conclusion, in the light of the findings and discussions, it was found out that "Computer-assisted Educational Games" 
is a must to provide with teaching of language skills and grammar in educational environments where technological developments and correspondingly digitalization are widely practiced.

\section{Recommendations}

As regards to the present study, recommendations for future research are listed as below:

1. The number and types of computer-assisted educational games can be increased. Games which are under the level of students could be boring for them. For this reason, for educational games which will be practiced in the classrooms, software support from experts may be desired. While designing educational games, feelings and opinions of students might be obtained via questionnaires. Especially educational games that are similar to current popular games could draw students' attention much more.

2. Designing or selecting computer-assisted educational games, it should be attentive to balance the proportion of entertainment and educational elements. Not to have that balance makes the achievement of the objectives difficult. In the phase of designing, while taking into consideration students' levels and developmental features, adopting a sexist approach should be avoided. Games should also provide an opportunity to practice what students know and evaluate what they have learned beyond knowledge transferring.

3. Teaching grammar should be practiced through an understanding based on implicit learning and emphasizing learning by discovery. Practices for skill development such as computer-assisted educational games designed for that purpose should be more used in the classroom. Seminars should be given to pre-service teachers who still study at a university and in-service teachers who work at schools for that purpose.

\section{Note}

This article is based on one part of M.A. thesis of the first author.

\section{References}

Akilli, G. K. (2007). Games and simulations: A new approach in education. In Games and Simulations in Online Learning: Research and Development Frameworks, 1-20. IGI Global. https://doi.org/10.4018/978-1-59904-304-3.ch001

Akkaya, A. (2011). Karikatürlerle dil bilgisi ögretimi [Teaching grammar with cartoons] (Doctoral dissertation). Selçuk University, Educational Sciences Institute, Konya, Turkey.

Akpınar, Y. (1999). Bilgisayar destekli ögretim ve uygulamalar [Computer-assisted instruction and practices]. Ankara: Anı Publishing.

Alessi, S. M., \& Trollip, S. R. (2001). Multimedia for learning: Methods and development. Boston, MA: Allyn \& Bacon.

Alkan, C. (2005). Eğitim teknolojisi [Educational technology] (4th ed.). Ankara: Anı Publishing.

Altunbay, M., \& Bıçak, N. (2018). Türkçe eğitimi derslerinde "Z Kuşağı” bireylerine uygun teknoloji tabanlı uygulamaların kullanımı [The use of technology-based applications suitable for "Generation Z" individuals in Turkish education courses]. Zeitschrift für die Welt der Türken/Journal of World of Turks, 10(1), 127-142.

Alyılmaz, C. (2010). Türkçe öğretiminin sorunları [Problems of Turkish teaching]. Turkish Studies, 5(3), 728-749. https://doi.org/10.7827/TurkishStudies.1629

Bangert-Drowns, R. L. (1985). Meta-analysis of findings of computer-based education with precollege students. Paper presented at the Annual Meeting of the American Educational Research Association, Chicago.

Bates, B. (2004). Game design: The art and business of creating games. US: Premiar Press.

Bayırtepe, E., \& Tüzün, H. (2007). Oyun-tabanlı öğrenme ortamlarının öğrencilerin bilgisayar dersindeki başarıları ve öz-yeterlik algıları üzerine etkileri [The effects of game-based learning environments on students' achievement and self-efficacy in a computer course]. Hacettepe University Journal of Education, 33, 41-54.

Bayturan, S. (2011). Ortä̈ğretim matematik ĕgitiminde bilgisayar destekli öğretimin, öğrencilerin başarıları, tutumlarl ve bilgisayar öz-yeterlik algllarl üzerindeki etkisi [The effect of computer-assisted instruction on the achievement, attitude and computer self-efficacy of students in mathemetics education]. (Unpublished doctoral dissertation), Dokuz Eylül University, Educational Sciences Institute, İzmir, Turkey. 
Berson, I., \& Berson M. (2003). Digital literacy for effective citizenship. Social Education, 67(3), 164-167.

Boyle, S. (2011). Teaching toolkit: An introduction to games based learning. College Dublin, 1-9. Retrieved from http://www.ucd.ie/teaching/t4media/UCDTLT0044.pdf

Buran, S. (2008). Bilgisayar destekli dil öğreniminin dinleme kavrama yetisi üzerine etkileri [The effects of computer assisted language learning on listening comprehension ability]. (Unpublished master's thesis), Atatürk University, Social Sciences Institute, Erzurum, Turkey.

Büyüköztürk, Ş., Çakmak, E. K., Akgün, Ö. E., Karadeniz, Ş., \& Demirel, F. (2013). Bilimsel araştırma yöntemleri [Research methods]. Ankara: Pegem A Academy.

Çatlak, Ş., Tekdal, M., \& Baz, F. Ç. (2015). Scratch yazılımı ile programlama öğretiminin durumu: Bir doküman inceleme çalışması [The status of programming teaching with scratch: A document review]. Journal of Instructional Technologies \& Teacher Education, 4(3), 13-25.

Ching-San, L., \& Ming-Horng, L. (2012). Using Computer Programming to Enhance Science Learning for $5^{\text {th }}$ Graders in Taipei. Paper presented at the Computer, Consumer and Control (IS3C), 2012 International Symposium on. Retrieved 8 October, 2019 from 10.1109/IS3C.2012.45

Çifçi, M. (2006). Türkçe öğretiminin sorunları [Problems of Turkish teaching]. In G. Gülsevin, E. Boz (Eds.), Türkçenin Çağdaş Sorunları [Contemporary Issues of Turkish] (2nd ed.). Ankara: Gazi Bookstore, 77-135.

Daloğlu, K. (2005). İlköğretim okullarında okutulan Türkçe ders kitaplarındaki dil bilgisi konuları üzerine bir araştırma [A Study on the grammar points in Turkish textbooks used in primary schools], (Unpublished master's thesis). Abant İzzet Baysal University, Social Sciences Institute, Bolu, Turkey.

Delice, A. (2010). Nicel araştırmalarda örneklem sorunu [The sampling issues in quantitative research]. Educational Sciences: Theory \& Practice, 10(4), 1969-2018.

Demir, C., \& Yapıcı, M. (2007). Ana dili olarak Türkçenin öğretimi ve sorunları [Turkish Teaching as a Special Teaching Field and its Problems]. Afyon Kocatepe University Journal of Social Sciences, 9(2), 177-191.

Demir, C. (2003). Türkçe Öğretiminde Zarf Tümleçleri. Türklük Bilimi Araştırmaları, (13), 407-423.

Demir, C. (2009). Türkçede Dil Bilgisi Öğretiminin Sorunları. Türkçenin Ĕ̆itimi ve Öğretimi Üzerine Konuşmalar. Ankara: TDK Yayınları, 59-68.

Demirci, A. (2008). Bilgisayar destekli sabit ve hareketli görsel materyallerin kimya öğretiminde öğrenci başarısinaetkisi [Computer assisted fixed and animated visual materials and their effect to students achivement in chemistry education] (Unpublished doctoral dissertation). Selçuk University, Institute of Science, Konya, Turkey.

Demirel, Ö., Seferoğlu, S., \& Yağcı, E. (2003). Öğretim teknolojileri ve materyal geliştirme [Instructional technology and material development]. Ankara: Pegem A Publishing.

Demirkol, S. (2007). Illkögretim 6, 7 ve 8. sinıf ders kitaplarındaki dilbilgisi terimleri üzerine bir inceleme [Investigation On Grammar Terms In The Books Of Turkısh Lesson Of 6, 7 And 8th Class of Primary Educatıon]. (Unpublished master's thesis), Firat University, Social Sciences Institute, Elazığ, Turkey.

Dempsey, J. V., Haynes L. L., Lucassen B. A., \& Casey M. S. (2002). Forty simple computer games and what they could mean to educator. Simulation and Gaming, 33(2), 157-168. https://doi.org/10.1177/1046878102332003

Dikmen, M., \& Tuncer, M. (2018). Bilgisayar destekli eğitimin öğrencilerin akademik başarıları üzerindeki etkisinin meta-analizi: Son 10 yılda yapılan çalışmaların incelenmesi [A meta-analysis of effects of computer assisted education on students' academic achievement: a-10-year review of achievement effect]. Turkish Journal of Computer and Mathematics Education, 9(1), 97-121.

Durukan, E. (2010). Türkiye Türkçesinde sözcük grupları ve öğretimi üzerine [Word groups and their teaching in Turkey Turkish language. Atatürk University Journal of Turkish Research Institute, 43, 145-166. https://doi.org/10.14222/Turkiyat1013

Durukan, E. (2011). Illköğretim 6. sinıfta bilgisayar destekli dil bilgisi öğretiminin başarı ve tutuma etkisi [The effect of computer assisted grammar teaching at primary school bth grade on success and attitude] (Unpublished doctoral dissertation). Atatürk University, Educational Sciences Institute, Erzurum, Turkey.

Durukan, E. (2012). Öğretim yazılımlarının farklı aşamalarda kullanımının başarıya etkisi: Dil bilgisi öğretimi örneği [Effect of using instructional software at different stages on success: Grammar teaching case]. International 
Journal of Turkish Literature Culture Education, 1(4), 134-150. https://doi.org/10.7884/teke.106

Erdem, İ., \& Başaran, M. (2010). Mezun oldukları bölümlerin öğretmenlerin dilbilgisi öğretimine ilişkin görüşleri üzerindeki etkisi. Journal of Turkology Research, 27, 321-339.

Erdem, İ. (2007). Ilköğretim 2. kademe dil bilgisi ögrretiminin sorunlart üzerine bir araştırma. [A Research on the problem of teaching grammar in the secondary schools] (Unpublished doctoral dissertation). Gazi University, Educational Sciences Institute, Ankara, Turkey.

Ergörün, O. (2010). Bilgisayar destekli fizik öğretiminin öğrenci başarısına ve öğrenci tutumlarına etkisi [The effect of the computer aided physics education students' success and attitudes] (Unpublished master's thesis). Yeditepe University, Social Sciences Institute, İstanbul, Turkey.

Garris, R., Ahlers, R., \& Driskell, J. E. (2002). Games, motivation, and learning: A research and practice model. Simulation \& Gaming, 33(4), 441-467. https://doi.org/10.1177/1046878102238607

Genç, Z., \& Karakuş, S. (2012, September). Tasarımla öğrenme: Eğitsel bilgisayar oyunları tasarımında Scratch kullanımı [Learning through design: Using Scratch in instructional computer games' design]. 5th International Computer \& Instructional Technologies Symposium. Firat University, Elazı̆̆.

Gredler, M. E. (2004). Games and simulations and their relationships to learning. Handbook of Research on Educational Communications and Technology, 2, 571-581.

Gülsevin, G., \& Boz, E. (2006). Türkçenin çă̆daş sorunları. Ankara: Gazi Kitabevi.

Güneş, F. (2013). Yapılandırıcı yaklaşımla dil bilgisi öğretimi [Teaching grammar with a constructivist approach]. Educational Sciences: Theory \& Practice, 9(3), 171-187.

Güneş, F. (2016). Türkçe Öğretimi Yaklaşımlar ve Modeller (4. bs.). Ankara: Pegem Akademi Yayınları.

Güngörmüş, G. (2007). Web tabanlı eğitimde kullanılan oyunların başarlya ve kalıcılı̆̆a etkisi [The effect of games used in web based education on success and permanency] (Unpublished master's thesis). Gazi University, Educational Sciences Institute, Ankara, Turkey.

Güven, A. Z. (2013). Dil bilgisi konularinin ögretim sorunları [Problems of Teaching Linguistics Subjects Abstract]. Journal of Language and Literature Education, 2(6), 1.

Güven, G., \& Sülün, Y. (2012). Bilgisayar destekli öğretimin 8. sınıf fen ve teknoloji dersindeki akademik başarıya ve öğrencilerin derse karşı tutumlarına etkisi. Journal of Turkish Science Education, 9(1), 68-79.

Hostetter, O. (2002, December). Video games - the necessity of incorporating video games as part of constructivist learning. In Game Research: The Art, Business and Science of Computer Games, James Madison University. Retrieved

from http://game-research.com/index.php/articles/video-games-the-necessity-of-incorporating-video-games-as-part-o f-constructivist-learning/

İşcan, A., \& Kolukısa, H. (2005). İlköğretim ikinci kademe dil bilgisi öğretiminin durumu, sorunları ve çözüm önerileri. Atatürk University Social Sciences Institute, 5(1), 209-308.

Kamacı, E., \& Durukan, E. (2012). Araştırma görevlilerinin eğitimde tablet bilgisayar kullanımına ilişkin görüşleri üzerine nitel bir araştırma (Trabzon örneği) [A qualitative study on research assistants' views about using tablet $\mathrm{pc}$ in education (Trabzon sample)]. International Journal of Turkish Literature Culture Education, 1(3), 203-215. https://doi.org/10.7884/teke.72

Kara, Y. (2009). Özel öğretici yazılımın kullanıldı̆̆ı bilgisayar destekli öğretim yönteminin öğrenci başarısına, kavram yanılgilarına ve tutumlarına etkisi [The effect of tutorial software used computer assisted learning method on student achievement, misconceptions, and attitudes]. Journal of Gazi Education Faculty, 29(3), 651-672.

Karadüz, A. (2007). Dil Bilgisi Öğretimi. (Editör: Ahmet Kırkkılıç, Hayati Akyol). İlköğretimde Türkçe Öğretimi. Ankara: Pegem Akademi Yayıncılık, 281-308.

Kebritchi, M., Hirumi, A., \& Bai, H. Y. (2010). The effects of modern mathematics computer games on mathematics achievement and class motivation. Computers \& Education, 55(2), 427-443. https://doi.org/10.1016/j.compedu.2010.02.007

Kerimoğlu, C. (2016). Dilbilgisi yazımı ve ögretimi [Grammar writing and teaching] (2nd ed.). Ankara: Pegem Academy Publishing. https://doi.org/10.14527/9786053184119 
Kiili, K. (2005). Digital game-based learning: Toward an experiential gaming model. The Internet and Higher Education, 8(1), 13-24. https://doi.org/10.1016/j.iheduc.2004.12.001

Korkusuz, M. E., \& Karamete, A. (2013). Educational game development models. Necatibey Faculty of Education Electronic Journal of Science \& Mathematics Education, 7(2), 78-109. https://doi.org/10.12973/nefmed203

Koşar, E. (2002). Öğretim teknolojileri ve materyal geliştirme. Bursa: Ezgi Kitabevi.

Köseoğlu, Ö. (2012). Sosyal ağ sitesi kullanıcılarının motivasyonları: Facebook üzerine bir araştırma [Motivations of social networking site users: A study on Facebook]. Selçuk University Academic Journal of Communication, 7(2), 25-81.

Kula, A., \& Erdem, M. (2005). Öğretimsel bilgisayar oyunlarının temel aritmetik işlem becerilerinin gelişimine etkisi [The effect of educational computer games on the development of basic arithmetical operation skills]. Hacettepe University Journal of Education Faculty, 29(29), 127-136.

Kulik, J. A. (1983). Synthesis of research on computer-based instruction. Educational Leadership, 41(1), 19-21.

Linderoth, J., Lantz-Andersson, A., \& Lindström, B. (2002). Electronic exaggerations and virtual worries: Mapping research of computer games relevant to the understanding of children's game play. Contemporary Issues in Early Childhood, 3(2), 226-250. https://doi.org/10.2304/ciec.2002.3.2.6

Malta, S. E. (2010). İlköğretimde kullanılan ĕgitsel bilgisayar oyunlarının öğrencilerin akademik başarılarına etkisi [The effects of educational computer games that used in elementary education on academic achievement], (Unpublished master's thesis). Sakarya University, Social Sciences Institute, Department of Computer and Instructional Technologies, Sakarya, Turkey.

McFarlane, A., Sparrowhawk, A., \& Heald, Y. (2002). Report on the educational use of games. TEEM (Teachers Evaluating Educational Multimedia): Cambridge.

Naba'h, A., Hussain, J., Al-Omari, A., \& Shdeifat, S. (2009). The effect of computer assisted language learning in teaching english grammar on the achievement of secondary students in Jordan. The International Arab Journal of Information Technology, 6(4), 431-439.

Özdamar, K. (2004). Paket programlar ile istatistiksel veri analizi (çok değişkenli analizler). Eskişehir: Kaan Kitapevi.

Özer, H. H. (2016). Eğitimde oyunlaştırılmış öğrenme ortamlarının öğrenci başarısına ve uygulamaya yönelik etkisi: ClassDojo örneğ $i$ [The effect of gamificition learning environments for student's success in education: Classdojo example], (Unpublished master's thesis). Near East University, Educational Sciences Institute, Nicosia, Cyprus.

Öztürk, D. (2007). Bilgisayar oyunlarının çocukların bilişsel ve duyuşsal gelişimleri üzerindeki etkisinin incelenmesi. [A study of the effects of computer games on children's cognitive and affective development], (Unpublished master's thesis). Dokuz Eylül University, Educational Sciences Institute, İzmir, Turkey.

Papestrergiou, M. (2009). Digital game-based learning in high school computer science education: Impact on educational effectiveness and student motivation. Computers \& Education, 52(1), 1-12. https://doi.org/10.1016/j.compedu.2008.06.004

Pehlivan, A., Aydın, İ. S., \& Uyumaz G. (2018). Dil bilgisi öğrenmeye ilişkin tutum ölçeğinin geliştirilmesi ve psikometrik özelliklerin belirlenmesi [Developing Attitude Scale and Determining Its Psychometric Qualities in Learning Grammar]. Modern Journal of Language Teaching Methods (MJLTM), 8(9), 254-267.

Pektaş, M. (2008). Biyoloji öğretiminde yapılandırmacı yaklaşımın ve bilgisayar destekli öğretimin öğrenci başarısı ve tutumlarina etkisi. [The influence of constructivist approach and computer assisted instruction in biology teaching on the students achievements and attitudes], (Unpublished doctoral dissertation). Gazi University, Educational Sciences Institute, Ankara, Turkey.

Polat, E., \& Varol, A. (2012, February). Eğitsel bilgisayar oyunlarının akademik başarıya etkisi: Sosyal bilgiler dersi örneği [Educational computer games effect of academic success: Example of Social Sciences Course]. Academic Informatics Conference, Uşak University, Uşak, Turkey.

Prensky, M. (2001). Digital natives, digital immigrants part 1. On the Horizon, 9(5), 1-6. https://doi.org/10.1108/10748120110424843

Prensky, M. (2007). Digital game-based learning. St. Paul, MN: Paragon House. 
Radoff, J. (2011). Game on: Energize your business with social media games (pp. 24-32). Hoboken. NJ: Wiley.

Ragasa, C.Y. (2008). A comparison of computer-assisted instruction and the traditional method of teaching basic statistics. Journal of Statistics Education, 16(1), 10. https://doi.org/10.1080/10691898.2008.11889556

Sağır, M. (2002). İlköğretim Okullarında Türkçe Dil Bilgisi Öğretimi. Ankara: Nobel Yayın Dağıtım.

Sanjanaashree, P., \& Soman, K. P. (2014, January). Language learning for visual and auditory learners using scratch toolkit. In 2014 International Conference on Computer Communication and Informatics (pp. 1-5). IEEE. https://doi.org/10.1109/ICCCI.2014.6921765

Sardone, N. B., \& Devlin-Scherer, R. (2009). Teacher candidates' views of digital games as learning devices. Issues in Teacher Education, 18(2), 47-67.

Scratch About. (2015). Retrieved December, 10, 2018 from https://scratch.mit.edu/about

Seferoğlu, S. (2006). Öğretim Teknolojileri ve Materyal Tasarımı. Ankara: PegemA Yayıncılık. https://doi.org/10.14527/9786050370522

Sever, S. (2015). Türkçe Öğretimi ve Tam Öğrenme (6. bs.). Ankara: Anı Yayıncılık.

Shagga, A., \& Omar, D. (2012). The effectiveness of using computerized educational games on developing aspects of English grammar for deaf ninth graders in Gaza Governorates. (Master's thesis), Al Azhar University, Faculty of Education, Gaza.

Siang, A. C., \& Rao, R. K. (2003, December). Theories of learning: a computer game perspective. In Proceedings of Fifth International Symposium on Multimedia Software Engineering (pp. 239-245). IEEE. https://doi.org/10.1109/MMSE.2003.1254447

Smith, L., \& Mann, S. (2002, July). Playing the game: A model for gameness in interactive game based learning. In Proceedings of the 15th Annual NACCQ. Hamilton, New Zealand.

Sönmez, V. (1993). Program Geliştirmede Öğretmen Elkitabı. Ankara: Adım Yayıncılık.

Squire, K., \& Barab, S. (2004, June). Replaying history: Engaging urban underserved students in learning world history through computer simulation games. In Proceedings of the 6th International Conference on Learning Sciences (pp. 505-512). International Society of the Learning Sciences. Retrieved from https://www.academia.edu/1317083/Replaying_history_Engaging_urban_underserved_students_in_learning_w orld_history_through_computer_simulation_games

Sümbüloğlu, K., \& Sümbüloğlu, V. (1993). Biyoistatistik. Ankara: Özdemir Yayıncılık.

Şahin, H. B. (2016). Ĕgitsel bilgisayar oyunlartyla destekli matematik öğretiminin ögrencilerin akademik başarlarına ve duyuşsal özelliklerine etkisi [The effect of educational computer games supported mathematics teaching on student's academic success and affective characteristics]. (Master's thesis), Osmangazi University, Educational Sciences Institute, Eskişehir, Turkey.

Şahinci, C. (2011). İlköğretim ikinci kademede dil bilgisi konularının öğretimine ilişkin Türkçe öğretmenlerinin görüssleri [The views of Turkish teachers on teaching grammar subjects in second primary education], (Unpublished master's thesis). Niğde University, Social Sciences Institute, Niğde, Turkey.

Şaşmaz Ören, F., \& Erduran Avcı, D. (2004). Eğitimsel oyunla öğretimin fen bilgisi dersi “güneş sistemi ve gezegenler" konusunda akademik başarı üzerine etkisi [The effect of educational game teaching on academic achievement in science education course in subject of "solar system and planets"]. Ondokuz Mayls University Journal of Faculty of Education, 18, 67-76.

Şimşek, N. (1997). Derste Ĕgitim Teknolojisinin Kullanımı. Ankara: Ami Matbaası.

Taşdemir, Ş., \& Şüyun, S. B. (2016). Bigisayar oyun tasarımı ve eğitsellik kazandırılmasına yönelik bir yaklaşım [Computer game design and an approach intended to gain educationality to the computer game design]. Journal of Selçuk- Technics, 15(2), 113-124.

Tural, H. (2005). Illköğretim matematik öğretiminde oyun ve etkinliklerle ögrretimin erişi ve tutuma etkisi [The Effects of Teaching Mathematics in Elemantary School by Games and Activities on Achievement and Attitude]. (Master's thesis), Dokuz Eylül University, Educational Sciences Institute, İzmir, Turkey.

Turvey, K. (2006). Towards deeper learning through creativity within online communities in primary education. Computers \& Education, 46(3), 309-321. https://doi.org/10.1016/j.compedu.2005.11.004 
Uğurel, I. (2003). Ortaöğretimde oyunlar ve etkinlikleri ile matematik öğretimine ilişkin öğretmen adaylarl ve ögretmenlerin görüsleri. [The Ideas of mathematics teacher candidates and mathematics teachers related of teaching mathematics with mathematical game and activities in high school level] (Master's thesis). Dokuz Eylül University, Social Sciences Institute, İzmir, Turkey.

Ural, M. N. (2009). Ĕgitsel bilgisayar oyunlarının eğlendirici ve motive edici özelliklerinin akademik başarıya ve motivasyona etkisi [The effect of entertaining and motivational properties of educational games to academic achievement and motivation]. (Doctoral dissertation), Anadolu University, Educational Sciences Institute, Eskişehir, Turkey.

Uygun, M. (2008). Bilgisayar destekli bir öğretim yazılımının ilköğretim 4. sinıf ögrrencilerinin kesirler konusundaki başarl ve matematiğe karșl tutumuna etkisinin incelenmesi [Investigation of the effects of an educational software on 4th grade primary school students? attitudes towards mathematics and their achievements on fractions] (Master's thesis). Abant İzzet Baysal University, Social Sciences Institute, Bolu, Turkey.

Üçgül, M. (2006). The impact of computer games on students' motivation. (Master's thesis), Middle East Technical University, Science Institute, Ankara, Turkey.

Ünal, F. T., \& Köse, M. (2014). Türkçe dersine yönelik tutum ölçeği geliştirilmesi: bir geçerlilik ve güvenirlik çalışması[Devoloping a Turkish Lesson Attitude Scale: A Validity and Reliability Study]. Bartin University Journal of Faculty of Education, 3(2), 233-249. https://doi.org/10.14686/BUEFAD.201428180

Yağız, E. (2007). Oyun tabanlı öğrenme ortamlarının ilköğretim öğrencilerinin bilgisayar dersindeki başarıları ve öz-yeterlik algllarl üzerine etkileri [The effects of game-based learning environments on students' achievement and self-efficacy in a primary school computer course], (Unpublished master's thesis). Hacettepe University, Science Institute, Ankara, Turkey.

Yalçın, A. (2002). Türkçe öğretim yöntemleri ve yeni yaklaşımlar [Turkish teaching methods, new approaches]. Ankara: Akçağ Publishing.

Yaman, H. (2006). İlköğretim ikinci kademe dilbilgisi derslerinde kavram haritası tekniğinin öğrenci başarısına ve hatırlamaya etkisi [The effect of the concept map technique in grammar lessons during the second level of the primary education on the student success and the act of remembering] (Doctoral dissertation). Marmara University, Educational Sciences Institute, İstanbul, Turkey.

Yaman, H. (2011). Yapılandırmacı yaklaşıma uygun dil bilgisi etkinlikleri. Ankara: Nobel Yayıncılık.

Yanpar, T., \& Yıldırım, S. (1999). Öğretim teknolojileri ve materyal geliştirme [Instructional technologies and material development]. Ankara: Anı Publishing.

Yapıc1, M. (2004). İlköğretim dilbilgisi konularının çocuğun bilişsel düzeyine uygunluğu [The appropriateness of grammar courses' subjects in elementary schools for the cognitive levels of children]. Illkögretim Online, 3(2), $35-41$.

Yılmaz, E. A. (2017). Oyunlaştırma (4. bs.). İstanbul: Abaküs Yayıncılık.

Yılmaz, E. A. (2018). Yeni Nesil Motivasyon İş’te Oyunlaştırma. İstanbul: Ceres Yayınları.

Yiğit, A. (2007). İlköğretim 2. sinıf seviyesinde bilgisayar destekli eăitici matematik oyunlarının başarıya ve kalıcllğg etkisi [The effect of computer-assisted educational Mathematics games on academic achievement and retention of primary school 2nd grade students], (Unpublished master's thesis). Çukurova University, Adana, Turkey.

Zobar, Y. (2010). Bilgisayar destekli ögrretimin ilköğretim üçüncü sınıf öğrencilerinin başarısı ve tutumuna etkisi [Effect of computer-aided instruction in the elementary third grade students achievement and attitudes of the course], (Unpublished master's thesis). Sakarya University, Social Sciences Institute, Sakarya, Turkey. 